\title{
Det er hvad jeg kalder at oversætte Digte: Grundtvig as translator
}

\author{
By S. A. J. Bradley
}

Grundtvig was not the first translator, and will not be the last, to wonder: why bother with a task so toilsome if its reward is to be put down as a hack who merely paraphrases in one language the discourse of a real poet in another?

In 1815 Grundtvig reviewed a review by P. E. Müller ${ }^{1}$ of the editio princeps of Beowulf, newly published in Copenhagen by the venerable Privy Archivist and Counsellor of State, G. J. Thorkelin (1752-1829). ${ }^{2}$ In the course of his fairly scathing critique of the reviewer's, and indeed of Thorkelin's, understanding of their subject, Grundtvig offered his own rhyming verse translation of a disputed section of the text and took the opportunity to advertise his intention of producing a Danish translation of the whole of Beowulf, in order to save the reputation of Danish scholarship. When Müller loftily tut-tutted over Grundtvig's »sædvanlige galdefulde Maade" [customary splenetic manner] of attack, and barbed his welcome for the proposed translation by murmuring den digteriske Oversættelse bliver til en vilkaarlig Paraphrase« [as long as the poetic translation doesn't turn out to be an arbitrary paraphrase], ${ }^{3}$ Grundtvig was in turn stung into a huffy retort:

Om Rec. har det venlige Haab at mine rimede Oversættelser bliver en vilkaarlig Paraphrase det være hans Sag, men naar han ei turde kalde Prøven saa, havde han gjort bedre i at tie med Sligt, der jo ikke beviser Andet end en slem Mistanke, ingen af mine faa rimede Oversættelser hjemler. Vil forresten Nogen kalde en saadan Oversættelse, som den jeg her har begyndt, en Paraphrase, da har jeg Intet derimod og kan en Anden gjøre det bedre, skal det være mig kjært, thi jeg har sandelig Saameget at bestille, at jeg ei vilde paatage mig et saa møisommeligt Arbeide, dersom jeg ikke troede at gjøre mit Fædreneland en Tjeneste hermed. ${ }^{4}$

If the reviewer has the amiable hope that my rhymed translation will be an arbitrary paraphrase, that is his problem. But since he did not dare to call the sample passage so, he would have done better to shut up with such 
remarks which reveal nothing other than a nasty misconception which none of my few rhymed translations admits. Incidentally, if anyone wants to call such a translation as I have here started upon a paraphrase, well I have nothing against that; and if someone else can do it better I should be delighted because really I have so much to see to that I would not take upon myself so toilsome a task if I did not believe I was doing my fatherland a service by it.

His tone of surprised insouciance at the indignation of first Müller's, and then Thorkelin's response - where Thorkelin exclaimed at the end of one forensic dissection of Grundtvig's translation: "Hvilken Oversættelse! Hvilken Galskab! « [What a translation! What madness!] - was surely contrived. It was he who had launched the quarrelsome issue of translation, and through it his gratuitous assault (as some, even among his friends, saw it ${ }^{6}$ ) upon one of the grand old men of Danish antiquarianism.

As soon as Grundtvig had first set to work studying Müller's review alongside the edition, he had discovered that Müller, knowing no Anglo-Saxon, had relied upon the Latin parallel translation furnished in Thorkelin's edition; and he was soon able to detect moreover that not only had Müller on occasion misrepresented the Latin, but the Latin at times misrepresented the AngloSaxon of Thorkelin's version and Thorkelin had at times misunderstood much of the Anglo-Saxon of the manuscript. This compound garbling of an ancient cultural and linguistic monument through the various processes of recension offended more than Grundtvig's sense of the scholarly. That the language of translation was Latin and not Danish was in itself regrettable, Grundtvig thought: ${ }^{7}$

At Oversættelsen er latinsk, kunde vel Mange beklage, og spørge, hvor længe vi skal vedblive at udgive Nordens gamle Mindesmærker for de Fremmede paa de Danskes Bekostning...

That the translation is Latin many could well complain about and ask how long we are to go on publishing the ancient memorials of the North for foreigners at the Danes' expense... 
However, he was prepared to acknowledge that an obligation was owed to international scholarship and that this warranted the use of the scholarly lingua franca of Latin for the parallel translation. The corresponding obligation towards the Danish people was to present the poem in a Danish translation which displayed its poetic qualities:

...dog vilde denne Klage her have mindre Grund, da et saadant Digt fra første Færd maae udgives for de Boglærde i alle Lande, og bør ei fremtræde for det danske Folk uden i sin velbehagelige poetiske Skikkelse.

...though this complaint would have less foundation here since such a poem must from the first outset be published for scholars in all countries, and ought not to come before the Danish folk except in its well-pleasing poetic form...

For the process of cultural transmigration he has at the back of his mind here, he elsewhere uses the concept of fordanskning: to fordanske - transmute into Danish - was a comprehensive task, as we shall see, not exactly coextensive with overscttelse, translation. Meanwhile, he felt justified in grumbling that it was negligent of the editor not to have furnished the edition at least with a clear synopsis in Danish, the modersmaal of that readership whose history it was that the poem preserved:

...Derimod var det sømmeligt, at enten Udgiveren eller en Anden forklarede paa Modersmaalet Kvadets Indhold, og viisde hvad vi alt flux kunne skjønne om dets poetiske og historiske Værd; og da Udgiveren hverken paa Latin eller Dansk havde opfyldt dette Ønske, besluttede jeg at giøre det efter Evne.

... On the other hand it would be fitting that either the editor or some other explained in the mother-tongue the poem's content and showed what we straight away could appreciate about its poetic and historical worth; and since the editor had fulfilled this desire neither in Latin nor in Danish, I resolved to do it as best I could. 
Translation, then, can be a tool in the service of the fatherland which pays homage to the mother-tongue. Proving and improving the mother-tongue was of course a preoccupation through the whole of Grundtvig's working life. Late in his life, on New Year's Day 1868, he told his Vartov congregation:

Intet Folk kan i det hele blive noget andet end sit eget Tungemaal mægtigt ... Før end man derfor kan vide, om kristelig og stormenneskelig Oplysning kan komme til at blomstre hos et Folk, da maa man først vide, at Folkets Modersmaal har Ord og Udtryk for alle Kristendommens særegne Begreber og Lærdomme, hvad der først viser sig, naar Bibelen eller de Kristnes hellige Skrift skal oversættes, og har da for vort Folks og danske Modersmaals Vedkommende viist sig alt for Aarhundreder siden. ${ }^{8}$

No people can in general have mastery in any other than its own native language ... Therefore before one can know whether enlightenment concerning Christianity and its great figures can come to flourish within a people, one must first know that the people's mother-tongue has words and expressions for all of Christianity's specific concepts and doctrines, which first reveals itself when the Bible or the Christians' holy scriptures have to be translated - and which in respect of our people and of the Danish mother-tongue revealed itself centuries ago.

Back in 1810 his experiments in translating the Icelandic Edda-poetry had been concerned with enriching the mother-tongue with a less Christian-explicit language recovered from or modelled upon its most ancient Nordic sources. Like poets (including translators) across the ages Grundtvig tried at this time, through the medium of translation, to coin new words out of old ones, to restore the currency of obsolescent or obsolete words, particularly dialect words, to extend the rhetorical scope of the present Danish language by constructing within it new rhetorical patterns of syntax.

These are processes also familiar in the history of the English language at least from the time of King Alfred, or even, in Grundtvig's view (in so far as he was prepared to accept the biblical 'paraphrases' in Oxford Bodleian Library Junius 11 as the poetry of Cædmon), as early as the seventh century. ${ }^{9}$ 
Rather more recently, Seamus Heaney, speaking as a translator-poet, affirms in the Introduction to his translation of Beowulf what he had earlier argued in extenso in his 1976 Beckman Lecture, Englands of the Mind - that is, the significance to the poet of 1 the word as an etymological occurrence, as symptom of human history, memory and attachments. $\|^{10}$

As regards their sense, words come to us not as definite shapes with sharpdefined edges but as a core of meaning with a penumbra of associations, some of them personal to the individual user or hearer, and some collective and communal, often forming part of the history of the contexts in which the word has been used over the generations - "symptoms of human attachments" Heaney calls them. It is typically and distinctively within the poet's craft, he suggests, to have a heightened sensitivity to the associative force of words, and thus to achieve a complexity of meaning within the relative economy of words that poetry so typically is. So Heaney permits himself in his recreation of Beowulf the use of both antique and dialect words which have associations with Ireland and Irish and these he uses to create a kind of subtext to his rendition of this earliest English poem - a subtext that is both personal and political, having to do with the resolution of conflicts, within himself, and also within the two nations, between Englishness and Irishness, England and Ireland.

Hence, for example, the authentic etymological nuance of Heaney's ithe life they had been lent « for loenan lifes (2845), restoring the Christian colouring so routinely blurred by translators and glossators as 'transitory life'; hence his 'thole' for 'suffer' (for Heaney the word, now obsolete in standard English after valiant service through Anglo-Saxon and Middle English, embeds in his poem associations which are personal as well as historical, and his justification is worth reading in the context of this present discussion ${ }^{11}$ ), and hence his archaisms and dialect words such as 'storied leader', 'snakefolds', 'graith', 'sept', 'brehon' and 'bawn'. Thus Heaney's purpose (obviously enough) is not to achieve as nearly as possible in the host language (Modern English) the standard dictionary equivalent of the words of the source-text. For Heaney as poet, other imperatives supervene. There is inevitably entailed an ideological motivation, both public and private, general and individual, which articulates, explicitly or implicitly, a conviction that in language resides the most fundamental character, the heart or the genius of the speech community from which the 
poet constructs his own identity and back to which the poet speaks through his poetry.

But beyond this, there is a sense in which it is true that no translator tells us, in precise equivalences, what an Anglo-Saxon source absolutely says. Only the source itself is itself. All translations are reports of what the source says to the translator. All translations are, at best, the best approximations the translator can find in his own language (a language which, by definition, exists currently to express the contemporary cultural perceptions of his own speech-community) for the language of the source-text (a language which, by definition, existed then to express the then-contemporary cultural perceptions of its speech community). The translator can know only in part the cultural nuances of AngloSaxon in use among Anglo-Saxons; and the translator's own available terminology will often only approximately match in the full range (in terms of both under-reaching and over-reaching) of its semantic nuances the AngloSaxon terminology for which it is substituting.

A simple and familiar example is Old English beot (nouns beot and beotword, verb gebeotian). We learn from the poetry of a semi-formal 'heroic' ritual whereby a man would make a pledge, usually of a martial kind, in a witnessed context such as a feast, which he was then bound in honour to fulfil. This kind of pledge is called beot; to utter such a pledge is gebeotian; and the words uttered are beotword. But beotword can also be bragging words, known to be self-glorifying or hollow. For this reason, the word 'pledge' is not a satisfactory translation in all circumstances where beot is used; and in any case 'pledge' only weakly conveys the cultural sense of formal social ritual implicit in beot and gebeotian. A routine translation for beot-almost a kind of tacitly agreed evasion among desperate translators - is 'boast'. But 'boast' in Modern English usage, reflecting modern English cultural values, is almost exclusively pejorative. The half-fossilised usage "It is my proud boast that... « and the now rather nebulous sense in "The Rundetaarn boasts one of the finest views of Copenhagen « form a fuzzy penumbra of meaning about the commonly-perceived core meaning of 'bragging'. The result is that readers unfamiliar with Old English, and working from the translation, may feel a pang of misgiving when they read of Beowulf's boasting; they may even, conditioned by a literary tradition postdating Beowulf, form an anticipation that the hero is going to 'fall' as a consequence of hybris. 
Similar perplexities attend words associated with the heroic concept we often translate as 'pride' - and with many other key concept-words. To some extent the translator can pick his way through the problem by using two or more words to translate the one Anglo-Saxon word, depending upon the context. Grundtvig was therefore right to dismiss Thorkelin's criticism that he used different Danish words in different places for the same Anglo-Saxon word (Grundtvig points out that Thorkelin has already cheerfully admitted to doing the same thing himself). ${ }^{12}$ But when all this is taken into account, one has to recognise the delusion entailed in the popular notion - such as was expressed by Bülow (below) and indeed Alfred (above) - that there really is such a thing as a »word for word" translation. All translation is a more or less drastic judgmental intervention between the reader and the source; and all translations are incomplete carryings-across, more so or less so; and it is a prerogative assumed by the translator to decide what is to be carried across and what is to be sacrificed for the sake of the particular priorities chosen for carrying-across.

One resort Heaney claims to himself in this highly problematic process of 'carrying across' the aspects of Beowulf that he prioritises is the use of the kind of special diction mentioned above, an attempt to put a special reserved diction into renewed and more universal circulation. The critics have taken differing attitudes to it, and it remains to be seen whether the archaisms and dialect words which need explaining in notes will be put down as a kind of private quirkiness in an otherwise public-voiced poem.

It is perhaps in something like this spirit, though in an absolutely more thorough-going way, and emphatically declaring himself to be a poet taking the poet's prerogative to himself in doing so, that Grundtvig in his translations of the Edda and of Saxo Grammaticus bids to construct a poetic language of translation which will import into, and put into beneficial circulation within the contemporary Danish language-community, words charged with the cultural associations of a Nordic antiquity, and will vest the forebears' sentiments and perceptions with matching robes of rhetoric in modern translation. His interest in 'etymologising' is conspicuous over this period; and the preeminent place of Anglo-Saxon within his etymologising activities, from 1815 onwards, is noted by Helge Toldberg and by the editors of the Registrant in their analysis of the contents of Grundtvig's papers. ${ }^{13}$ 
It is surely significant that according to the Loans Register of the Royal Library in Copenhagen one of the very first Anglo-Saxon texts borrowed by Grundtvig (on 5 September 1815) was King Alfred's English translation of Boethius' De Consolatione Philosophiae. ${ }^{14}$ No doubt his practical purpose was to use the Latin source as a 'control-text' while he worked to improve his primary understanding of Old English words and syntax; but we may assume that from the outset of his engagement with Anglo-Saxondom this process of negotiation between three languages fed his awareness of the complex linguistic processes, both within and outside the control of the translator, entailed in the transplantation of language-embodied cultural notions from one language (and era) to another. Certainly he comes later to describe Alfred's programme of translation and original composition in Moders-Maalet with apparent approval and speaks of »denne Skat af Oversættelser « »that treasure of translations « that Alfred has left. ${ }^{15}$

At any rate, though the surviving relics of his early work in this area include dry and academic-looking word-lists, ${ }^{16}$ it is indeed clear that Grundtvig's translation-activity is far from being hack-work mechanically done with a couple of dictionaries to hand. In the process of his negotiations between languages and language-embodied cultures is entailed a deep and complex treaty with language itself, such a treaty as we conventionally expect to encounter in original poetry and prose-writing, a treaty which is linguistically and literarily creative. Grundtvig the philologist, just like Heaney the philologist, develops to a great extent within and by virtue of his prior function as translator and as poet.

But the extremity to which Grundtvig took his translator's licence in 1810 brought him into public dispute, with no less an authority than the distinguished Danish linguist Rasmus Rask. ${ }^{17}$ Flemming Lundgreen-Nielsen has observed that the sample translation published by Grundtvig in January, $1810^{18}$ - the final portion of Helgakviða Hundingsbana II - »markerer højden af Grundtvigs norrøniserende sprog, til tider ganske uforståelig for læsere uden kendskab til oldislandsk « [marks the high-point of Grundtvig's 'norrønising' language, at times completely incomprehensible for readers without a knowledge of Old Icelandic]. Lundgreen-Nielsen continues: 
Den voldsomt norrøniserende, ja rekonstruerende stil har også farvet Grundtvigs egen prosa i indledningen, $i$ ordforråd og syntaks. Planen til en eddaoversættelse er i det sproglige konsekvent romantik: tilbage til sprogets rødder.

The violently 'norrønising', indeed reconstituting, style has also coloured Grundtvig's own prose in the Introduction, in vocabulary and in syntax. The plan for a translation of the Edda is, in linguistic respects, consistently Romantic: back to the roots of the language. ${ }^{19}$

So it was that Rask stepped in with his challenge:

Han priser Grundtvigs forsæt, men finder hans oversættelsesteknik forkert, fordi eddaen ikke som Bibelen skal oversættes ord for ord, en dansk eddaoversætter skal tage sproget »i sin mest dannede og forædlede Skikkelse«, ikke søge at omforme eller forny det til sit formål (sp. 530), en god oversættelse «maa være som Forfatteren vilde have udtrykt sig, om han havde talt og skrevet det samme Sprog « (sp. 531) - for resten et princip, Grundtvig i $1810^{\prime}$ erne skulle tilslutte sig ... Rask kritiserer Grundtvigs sprog for radskillige, dels næsten uforstaaelige, dels næsten utaalelige Figurer og Vendinger «, hans syntaks for de upassende »lutter løse Sætninger« (den asyndetiske paratakse) (sp. 531) og påpeger urigtigheder i oversættelsen ... Afsluttende karakteriserer Rask Grundtvigs dansk: »en alt for opskruet, tvungen, unaturlig og tildels uforstaaelig Stil, fuld af Islandismer, Solecismer og Germanismer«, en »Jagen efter Usædvanligheder og Særheder« i "ganske særegne og selvgjorte Ord og Vendinger, der støde os" (sp. 546547), den rette eddaoversætter må anvende mere islandsk sprogkundskab og have mere simpelhed og natur $\mathrm{i}$ det danske foredrag og mere enhed $\mathrm{i}$ versifikationen end Grundtvig. ${ }^{20}$

He esteems Grundtvig's intention but finds his method of translation wrong, because the Edda is not, like the Bible, to be translated word for word; a Danish Edda-translator must take the language win its most developed and refined form " not seek to reshape it or renew it to his own purposes (col. 530); a good translation »must be as the author would have expressed him- 
self had he spoken and written the same language« (col. 531) - a principle, incidentally, to which Grundtvig would commit himself in the 1810 s ... Rask criticises Grundtvig's language for $/ v a r i o u s$ partly almost incomprehensible, partly almost intolerable figures and expressions" and his syntax for the inappropriate »altogether discrete sentences" (asyndetic parataxis) (col. 531); and he points out mistakes in the translation ... Finally Rask characterises Grundtvig's Danish as wan all too exaggerated, contrived, unnatural and in part incomprehensible style, full of Icelandicisms, solecisms and Germanisms «, a quest after things out of the ordinary and eccentricities in ireally peculiar and home-made words and expressions which alienate us« (cols. 546-547); the proper Edda-translator has to employ greater knowledge of the Icelandic language and have greater simplicity and naturalness in his Danish diction and greater uniformity in versification than Grundtvig."

Not surprisingly, when some years later Grundtvig's loyal friend J. C. Lindberg reports $^{21}$ on P. E. Müller's forthcoming new edition of Saxo Grammaticus he has a regretful acknowledgement to make:

...skjøndt baade Anders Sørensen Vedels Oversættelse for $\sin$ Tid, og N. F. $S$. Grundtvigs for vore Dage burde have gjort Saxo til en kjær Folke-Bog, har den dog ingenlunde fundet saamange Læsere i Folket, som den fortjente, og enhver Ven af Danmark inderlig maatte ønske. Imidlertid forudsætter dog disse Oversættelser, at der hos det danske Folk maa være en Kjærlighed til Saxos Krønike tilbage... [col. 63].

...although both Anders Sørensen Vedel's translations for his time [15421616], and N. F. S. Grundtvig's for our own day ought to have made Saxo into a cherished household book yet it has not at all found as many readers as it deserved and every friend of Denmark must heartily desire. But meanwhile these translations postulate that among the Danish people there must persist a love for Saxo's Chronicle.

The reading public had evidently passed its own judgment on the readability of Grundtvig's early translations. Eventually of course, notwithstanding all this 
early controversy about his oversattelsesteknik and his basic competence in the language and the culture of the Anglo-Saxons, Grundtvig went on to publish in 1820 the promised (threatened?) Danish translation of the poem, in rhyming and stanzaic verse, as Bjowulfs Drape. Et Gothisk Helte-Digt fra forrige Aartusinde af Angel-Saxiske paa Danske Riim ved Nik. Fred. Sev. Grundtvig Prcest.

By now, Beowulf had acquired some popular renown in Denmark, chiefly for its supposed historical content and for the testimony it ostensibly bore to the ancient values of the Danish kings and people. In his translation, therefore, Grundtvig is of course preeminently concerned to carry accurately across from Anglo-Saxon to Danish, from the ancient North to the modern North, the legendary-historical content, the ideas and the values of the original. As regards fidelity to the more casual sentiments, and the specific idiom and imagery of the Anglo-Saxon poet he allows himself considerable latitude, at times rendering the original more or less word for word (I use the phrase subject to my comments above), at other times sense for sense, and, when it suits, sometimes introducing quite new matter.

As regards the formal aspects of poetic style of the original, he allows himself a distinctly free hand: far from attempting any serious reproduction of the poet's alliterative rhetoric, he chooses (unlike Heaney) to work in a variety of metrical and strophic forms unmatched by anything in Anglo-Saxon literature, routinely using end-rhyme in a variety of patterns, where the poet universally uses the head-rhyme that is alliteration and never uses end-rhyme. This is one major reason why Grundtvig's Beowulf does not sound like the Anglo-Saxon Beowulf, whereas Heaney's (approximately) does. But as far as Grundtvig is concerned, to translate is to transmute into Danish (fordanske), and the poetic form no less than the language must be fordansket, transmuted into a Danish idiom. So he appears to say in his introduction to his rendition of The Battle of Brunanburh (Kcempevise om Bruneborg-Slaget, 1817). He gives a factual summary account of what happens in the poem, and then observes (italics are my own): ${ }^{22}$

Saaledes maa da Rimets Ord udtydes, men dermed er i mine Tanker Rimet ingenlunde oversat eller fordansket, det ligger som et Liig til Ravn og Ulv, og Aanden er borte, denne vil jeg nu søge at gribe og lade tale saa godt den 
kan med min danske Tunge, uden at udsige Andet end den gamle Skjald, og det er, som man veed, hvad jeg kalder at overscette Digte. ${ }^{23}$

This then is how the poem's words are to be construed - but to my mind the poem has by no means been translated or made into Danish thereby. It lies like a corpse for the raven and the wolf and its spirit is gone. This spirit I will now try to catch and allow to speak as best it can with my Danish tongue, whilst not saying anything other than did the ancient skjald. And this, as people know, is what I call translating poems.

This then is what he, Grundtvig, calls translating poetry; and he repeats the characterisation in Danne-Virke IV (1819) with reference to his own forthcoming rhyming translation of Beowulf:

Det ikke uvigtige, og i mine Øine mere indviklede end besvarede Spørgsmaal: hvordan man bør oversætte, agter jeg med det Første at gjøre til Gjenstand for en egen skriftlig Betragtning, om ei for Andet saa for at man kan sammenligne min Theorie med min Praxis, og undgaae baade at betragte mine Feiltagelser som forsætlige Misgreb, og mine overlagde Vendinger, som skjødesløs Flygtighed. Jeg vil derfor her lade min Praxis tale for sig selv, og i det jeg erklærer mig villig til at frafalde den, naar man kan overbevise mig om at jeg bør, maa jeg kun bede Vedkommende lægge Mærke til, at naar en Skribent som man indrømme Evne til selv at kunne forfatte Noget, der lader sig læse, giver sig af med at oversætte, og beviser at han gjør det med Flid og Eftertanke, da bør det neppe undre Nogen, at hans Arbeide bliver anderledes end de sædvanlige Oversættelser, og da bør man vist betænke sig to Gange, før man vrager hans Arbeide paa Grund af, at det er anderledes, end hvad Oversættere pleie at levere.

For det Første blev der Intet af den nye Udgave, hvortil det gamle Digt saa høilig trænger, men naar Professor Rask kommer tilbage, tænker jeg vi udføre vort Forsæt, og da, om ei før, skal man lære, at jeg i min rimede Fordanskning ei viger fra Ordene, enten fordi jeg har oversprunget dem, eller for at gaae fra Texten, men kun fordi jeg troer, det er den eneste Maade, hvorpaa man kan oversætte et Digter-Vaerk, thi det er: efter min Forstand, 
at lade dets Aand udtrykke sine Forestillinger i et andet Sprog, ei blot da i andre Ord men og i andre Vendinger, naar disse ere de tilsvarende. ${ }^{24}$

The not unimportant, and in my eyes additionally complicated rather than answered question - how one ought to translate - I intend before long to make the object of a written consideration of my own, if for no other reason than that one can compare my theory with my practice and avoid both regarding my errors as deliberate mistakes and my well-weighed expressions as casual superficialities. I will therefore let my practice speak for itself; and because I declare myself willing to renounce it when it can be proved to me that I should, may I just ask those concerned to take note that when a writer who is acknowledged to have the talents himself to compose something that is fit to be read gives himself over to translating, and shows that he is doing it with diligence and thoughtfulness, then they ought not to be surprised that somebody's work comes out differently from the usual translations, and then one certainly ought to think twice before discussing his work on the ground that it is different from what other translators are wont to deliver.

For the time being, nothing has come of the new edition which this ancient poem so very much needs, but when Professor Rask comes back I imagine we shall carry out our intention: and then, if not before, people will learn that in my rhymed rendition into Danish I do not diverge from the words either because I have omitted them or in order to depart from the text, but solely because I believe that it is the only way in which one can translate a work of poesy; for this is: according to my understanding, to allow its spirit to express itself in another language, not only in other words but also in other expressions, when these are the corresponding ones.

Thus - to return to his published Bjowulfs Drape (1820) for examples - the Anglo-Saxon Swa rixode ond wið rihte wan / ana wið eallum, oðpcet idel stod / husa selest [144-146: So he reigned and strove against right, one against all, until useless stood the best of halls] $]^{25}$ becomes: 'Saa den Trold, fuld leed og grum, / Fik i Hallen Raade-Rum, / Ene, trods de Mange, / Helmed ei, før Kongens Gaard / Øde stod paa Tofte' [So the Trold, most vile and ruthless, got room to rule in the hall, the one against the many, and did not cease until the 
king's garth stood desolate upon its toft] - with its effective reproduction of ana wið eallum.

Deorc deapscua dugupe ond geogope, / seomade ond syrede; sinnihte heold / mistige moras; men ne cunnon / hwyder helrunan hwyrftum scripað [160-163: 'The dark death-shadow lurked and lay in wait for old and young; in endless night he ruled the misty moors; men know not where the familiars of hell go in their wanderings] becomes part of a ballad-like sequence of seven stanzas dwelling upon Grendel's feud against Hrothgar. Within this 'ballad' (opening 'Grændel, han ypped med Hrodgar en Kiv' [Grendel, he raised against Hrothgar a feud]) the cited passage is rather freely treated. But at the same time, it comprises a small tour-de-force on literal and symbolic darkness which, however far it diverges from the words and the rhetorical structure of the original, is strikingly within the spirit of the poem:

Sort saae det ud da, for Store og Smaa, Hvad ligned vel Dannemænds Vaande! Stene, som Klipper, paa Hjertene laae, Og gispende drog man kun Aande.

Sort saae det ud, hvor sig Trolden befandt,

Paa Mørket man der kunde tage,

Hyllet i Taage han kom og han svandt,

Hans Spor kunde Ingen opdage!

The outlook was black then, for great and for small - what compared with the grief of the Danes? Stones like boulders lay upon their hearts and only gaspingly they drew breath. // The outlook was black wherever the Trold appeared; there the mirk was palpable; shrouded in mist he came and he vanished, and none could discover his track.

His translation-vocabulary is rich in poetic compound words, often reflecting or reproducing the construction of Anglo-Saxon - and Icelandic - words: overmod for OE ofermod 'pride'; Brynje-Scerk for OE byrne 'mail-coat'; KystBefalingsmand and Sø-Borg-Høvedsmanden for the coastguard who is called simply weard and ombeht in the original. 
But now, we may ask: is Grundtvig solely concerned with bringing out the spirit of the original, or has he a conscious agenda or an unconscious habit of importing into the poem and retrospectively inserting into the record of antiquity the spirit (or a model of the wished-for spirit) of his own times? Beowulf is, in significant degree, a poem about kingship. It has sometimes been thought of as a 'mirror for princes'. Much of its vocabulary therefore serves quite naturally to create a substantial poetic lexis - a lush idiom of kingship and majesty - for the expression of a contemporary ideology close the Grundtvig's heart. But further than this, it can be shown that he insinuates images and terminology of kingship - the kingship of the Danes - 'Konge', 'Konning', and 'Drot - into contexts where they are only vaguely present or not present at all in the Old English text. A striking example is where Grundtvig responds to the prompt of eodor Scyldinga (428) 'prince of the Scyldings' with the rendition 'O Dannevirke-Drot' (p. 40), thus astutely importing the name of Denmark's ancient frontier against the Germans and tacitly conferring new legendaryauthority upon this emotive symbol of land and folk.

The gifstol 'gift-seat' (e.g. 168) on which kings ceremonially sit in the original is sometimes 'Throne' in Grundtvig's Danish, but also 'paa KongeStolen' (p. 7) corresponding with the original's vague on burgum (53), or the phrase 'paa Konninge-Stol' (p. 4) prompted by the vague verb ahte 'owned, ruled' (31). Scyld's funeral-ship, the rather neutral Anglo-Saxon cepelinges for (33) 'nobleman's vessel', becomes 'Konge-Snekke' (p. 4). He takes the AngloSaxon formulaic phrasing wine Deniga, frean Scyldinga (350-51) 'friend of the Danes, lord of the Scyldings' and from it makes Hrothgar 'Drotten, Folket ærer, / Som Daners bedste Ven' (p. 33), 'The King whom the people honour as the Danes' best friend'.

Still more boldly, and more polemically, does he render the English poet's rather formulaic statement of Hrothgar's naming of the hall Heorot: scop him Heort naman, / se pe his wordes geweald wide hoefde ['he shaped for it the name Heorot, he who widely held the power of his word']. Here Grundtvig (»Ja, mine Herrer, jeg er en gammel Royalist, det ved De nok« [Yes, gentlemen, I am an oldstyle Royalist. That you doubtless know ${ }^{26}$ ) envisages something rather specifically called 'Kongens Ord' which issues forth with executive force from amid the gathering of his warriors: 'Her Kæmper sad om breden Bord, / Og Kraft der var i Kongens Ord: / Han kaldte Borgen Hiorte' (p. 9) 
[Here warriors sat round the broad table, and there was power in the word of the king: he named the hall Heorot]. This is matched later by the image of God with the power of his fiat, the Providential Lord in his heaven - and Grundtvig seems already to be rehearsing the rhetoric of some of his later hymn-translations: 'Med Almagt throner Ærens Drot / I Himmel-Høielofte, / Han raader, styrer viist og godt' [p. I55: With omnipotence the King of Glory sits enthroned in the high hall of heaven; he governs and guides surely and well]. ${ }^{27}$

As a last example of the latitude that Grundtvig's fordanskning permitted (or required), a passage is taken which also conveniently serves to illustrate how Grundtvig reinforced the Christian-providential didacticism of the original poet in the process of translating. Grendel is dead. The Danes gather in Heorot to view the grisly sight of his arm, wrenched off in the struggle with Beowulf. King Hrothgar himself enters ceremonially with his queen. The next thirty-one lines are then given by the Anglo-Saxon poet to a speech by Hrothgar as he stod on stapole [stood on the stapol ${ }^{28}$ ] and gazed at Grendel's arm hung beneath the steep gilded roof of the hall. The speech opens Đisse ansyne Alwealdan panc / lungre gelimpe! Fela ic lapes gebad, / grynna cet Grendle; a mog God wyrcan / wunder cefter wundre, wuldres Hyrde [928-31: For this sight let thanks at once be given to the Almighty! Much enmity have I endured, griefs because of Grendel; God can always work wonder upon wonder, the Guardian of Glory].

The pattern of reversal in human affairs implicit in the words of Hrothgar and in the rhetorical structuring of the passage, especially of line 930, is an important motif of the Anglo-Saxon poem as a whole. It is encapsulated in such alliterative formulations as $P a$ wces cefter wiste wop up ahafen [128: Then after the feasting was weeping upraised (of Grendel's unanticipated attack after the idyllic inauguration of Heorot); swefep cefter symle [1008: sleeps in death after the banquet (of Grendel's fate after reigning seemingly unstoppably in Heorot)]. It is also illustrated in various anecdotes and didactic utterances throughout the poem, as in the passage discussed above, based upon Beowulf 1724 and following, and rendered by Grundtvig as: »Med Almagt throner Ærens Drot / I Himmel-Høielofte, / Han raader, styrer viist og godt, / Men underligt fuldofte, / Ja, sælsomt efter Herrens Dom, / Sig ofte vender Bladet om / Med Stand og Land og Lykke! « [p. 155: In omnipotence the King of Glory sits enthroned in the high hall of heaven; he governs and guides surely and well. But very often 
wondrously, yes mysteriously according to the Lord's decree, the page often turns as regards degree and land and fortune!].

It may be argued that Grundtvig's insight has registered here a key concept in the Anglo-Saxon poet's 'philosophy of history' - a concept on which the poet rests the guarded optimism that a Christian understanding of human history affords. The world is chronically unstable. The only worldly certainty is that nothings lasts. But the Christian certainty of the poet is that all that happens in the world happens under the eye of God and within the dispensation of his Providence; and that in the end (but the end will be beyond the grave and the Last Judgment) God and good will prevail and evil will pay the price of sin. It is to this judgment, the judgment of those who have stood firm in truth (the soffoeste), that the poet tells us Beowulf's soul departs upon his death. This guarded optimism, close to christianised Boethianism, is also expressed in another Anglo-Saxon poem known to Grundtvig (because he transcribed it from the Exeter Book). This is Deor, with its refrain »That passed away, so may this « (where that is the history of human triumphs and tragedies comprising the poet's story-hoard, and this is the poet's personal grief in this present time), and its turning-point when the man oppressed by the world's injustice comes to think that after all, all is within the forethought of the witig Dryhten, the wise Lord.

Grundtvig evidently sees this as a key idea in Beowulf, and finds it hinted at in Hrothgar's speech as an example, perhaps, of »dets religiøse Grundtone, " its underpinning religious tone, which he commends in his Introduction to Bjowulfs Drape (p. LII). He therefore resolves, within the (considerable) licence of allowing the Aand of the poet to speak through his Danish words, to make a rhetorical feature of this optimistic sentiment that things can change for the better in this world when God in his Providence wills it so. So the narration of Hrothgar's speech is recast in a twelve-strophe ballad-like form, with the refrain punctuating each strophe's narrative point with the wisdom: "Saa times og vel efter Vaande! « The sequence begins:

Stille stod nu den Drot saa prud,

Og høit lod han Ordene lyde:

Takket være al Magtes Gud 
For Synet mig undes at nyde!

Saa times og Vel efter Vaande!

Leed af Grændel Fortræd jeg meer

Og Fals, end i Hast er at melde,

Priset være den Gud, som teer

I Under paa Under sin Vælde!

Saa times og Vel efter Vaande!

[Still now stood the king so proud, and loud let his words sound forth: The God of all might be thanked for the sight it is granted me to enjoy! So weal also follows on woe! // More harm and treachery I have suffered from Grendel that can quickly be told. Praised be that God who manifests his power in wonder upon wonder! So weal also follows on woe!]

A great deal more analysis of Grundtvig's handling of Beowulf could be, and perhaps ought to be done along these lines, potentially to the illumination of various aspects of Grundtvig's thought and polemic; but the foregoing may serve to suggest that the contemporary-ideological nuance Grundtvig introduces by this overscettelsesteknik, if complex, is plain. Translation is the versatile medium for appropriating, reconstructing, adapting and rehabilitating an antiquity that could form part of a present national identity and a contemporary and future agenda for a Danish folk in the traumatic age of shifting power, unstable loyalties and dissolving frontiers that was the Napoleonic and post-Napoleonic era. When the translation is taken along with the lengthy essay on Beowulf written and published by Grundtvig in Danne-Virke II (Copenhagen, 1817) and with his Introduction to Bjowulfs Drape, it also becomes clear that the perspective of history within which the identity and destiny of the Danish folk were to be properly understood, now in this present age as in ancient times long past, was a Christian and providential one.

Amid the settling dust of the skirmish between Grundtvig, Müller and Thorkelin, Johan Bülow, who was patron of both Grundtvig and Thorkelin and was probably the peace-maker, wrote to Grundtvig. In his letter he assures him of his unchanged goodwill and confirms that he is ready to foot the bill for printing Grundtvig's translation of Beowulf as soon as it is prepared. But he ex- 
pressly wishes that Grundtvig "ville oversætte og udgive det, ikke allene poetisk, men og ordret« [will translate and publish it not only in a poetic version but also in a literal]. Grundtvig's answer finally comes in his Introduction to Bjowulfs Drape (p. XXXIv) published at last five years later (italics are mine):

Kun det maa jeg sige: jeg har studeret Digtet, som om jeg skulde oversætte det Ord for Ord ... men saaledes vilde jeg ikke overscette og har ikke oversat det, og dog tør jeg paastaae, at Oversættelsen er troe; historisk troe, saa jeg aldrig med Villie har forandret eller indskudt Noget, og poetisk troe, saa jeg af al Magt har stræbt at sige livlig hvad jeg saae i Kvadet.

I have to say just this: I have studied the poem as though I should translate it word for word ... but that is not the way I wanted to translate it, nor have I translated it so; and yet I dare assert that the translation is faithful: historically faithful, in that I have never wilfully altered or inserted anything, and poetically faithful, in that I have striven with all my might to say with vitality that which I saw in the poem.

"The toil of his formidable translation tasks, which sequestered him in his study, had in the long run a deadening effect on him, and it was with some relief that he accepted a living at Præstø, Zealand in $1821 \ldots$ « it has been said. ${ }^{29}$

One must beg leave to think less negatively of Grundtvig's labours in the exacting art of translation. Those who have themselves seriously engaged in this art will know that there are rich gains to be had in terms of a raised and greatly refined awareness of the character of the host language, just as of the source language - an awareness which may enhance one's response to other literature and even one's own creative use of language.

Bodily and emotionally wearisome translating and quarrelling about the nature of translation may well have been for Grundtvig, but life, not death, informs the words of Grundtvig's writings throughout the rest of his long years. Doubtless much of this linguistic vitality was stored in those days of toil and controversy when Grundtvig was a translator. ${ }^{30}$ 
1. Peter Erasmus Müller (1776-1834), doctor of theology, cleric, historian and philologist, Bishop of Sjælland from 1830, was a leading scholar in the field of early Scandinavian literature whose Sagabibliothek (1817-20) represented an important new stage in the emergence of modern scholarly study of the Icelandic sagas and their living legacy. As editor (1805-30) of Dansk Litteratur-Tidende (published up to 1811 as Kjøbenhavnske lcerde Efterretninger), Müller enjoyed the confidence of the absolutist government, which readily wielded censorship over the press, to the extent that he was permitted to publish anonymous articles. The journal carried the work of a whole series of distinguished Danish scholars in various fields over the period of his editorship. For Grundtvig and his supporters in the 1820s Müller represented the contemporary threat of Rationalism to true religion, so he and his journal were often their target for sometimes merely opportunistic attacks. Information from the Dansk Biografisk Leksikon, 3rd edition, vol. X(Copenhagen, 1982). Müller's review of Thorkelin was in Dansk Litteratur-Tidende nos. 26 and 27, and his response to Grundtvig's attack was in no. 29, all in 1815. Extracts from this debate on the textual editing and the translating of Beowulf, which constitutes one of the very earliest monuments in the history of modern Beowulf scholarship, are translated into English in T. A. Shippey and Andreas Haarder, Beowulf: The Critical Heritage (London and New York, 1998).

2. Grundtvig's articles came out in Nyeste Skilderie af Kjøbenhavn, Tolvte Aargang (1815), nos. 60, 63, 64, 65, 66, 70, 71, and 72. Thorkelin's two-part answer, 'Svar til: »Et Par Ord om det nys udkomne angelsaxiske Digt”, i Skilderiets No. 60.'- a mixture of real gravitas, undignified irony, judiciousness and dogged wrong-headedness - came out in nos. 67 and 68 (Tuesday 22 August and Saturday 26 August, 1815). A brief anonymous item appeared in no. 75, ridiculing Grundtvig for frenetically cramming himself with diverse learning so that he might instantly step forward as teacher of that which, two weeks ago, by his own admission, he did not understand. Finally in no. 85 (Tuesday 24 October, 1815), the editor of the journal, Pastor Børge Pontoppidan, brought the skirmishing to an end with a warm defence of Grundtvig (»Hvo af vore Lærde kan skrive - at jeg blot skal nævne Sproget een eneste Side Dansk med samme Originalitet, Kraftfylde og Skiønhed som Grundtvig?« [Who amongst our learned can write - if I shall mention only language - one single page of Danish with the same originality, abundance of strength and beauty as Grundtvig?]). He concludes with a pastorly exhortation to Grundtvig to continue his work for the fatherland's name and honour, for religion and for truth.

3. In Dansk Litteratur-Tidende for 1815, no. 29, cols. 461-462.

4. 'Et Par Ord om det nys udkomne angel-saksiske Digt (Slutning; see forr. No. 60, 63)' in Nyeste Skilderie af Kiøbenhavn, Tolvte Aargang, no. 66 (Saturday 19 August, 1815).

5. G. J. Thorkelin, 'Svar til: "Et Par Ord om det nys udkomne angel-saksiske Digt«, i Skilderiets No. 60.' in Nyeste Skilderie af Kiøbenhavn, Tolvte Aargang, no. 67 (Tuesday 22 August, 1815). 
6. On 4 January 1816 , for example, Jens Hornsyld wrote to Grundtvig speaking also for others among his friends, and reproached him for having handed his adversaries opportunity to scorn both him and true religion, through his recent polemical publications including his disrespectful attack on Thorkelin; G. Christensen and S. Grundtvig (eds), Breve fra og til N. F. S. Grundtvig Vol. I, 1807-20 (Copenhagen, 1924), p. 397.

7. Nyeste Skilderie af København, no. 60 (Saturday 29 July, 1815), col. 945.

8. In C. J. Brandt, N. F. S. Grundtvigs Sidste Proedikener i Vartov Kirke 1861-72, vol. 2 (Copenhagen, 1880), pp. 58-60.

9. In a letter to his bishops datable about 890 , appended as a preface to his own translation of the Cura Pastoralis of Gregory the Great, Apostle to the English, Alfred urged the provision of an education for the sons of freemen with English, not Latin, as the medium; and he announced the project, already started under his own participative direction, to translate into English from Latin those works of the Christian heritage which it was most needful for all people to know. Alfred there described his translation of Gregory as being sometimes word for word, sometimes sense for sense. For discussion of the significance of Cædmon for Grundtvig's conceptualisation of his own high calling as a poet in the lineage of the Northern skjald see my articles: 'The recovery of England's $"$ Skrinlagt Fortid«: A progress report', GS (1999), pp. 138-61; 'Stridige Stykker jeg snild forbandt: Grundtvig's creative synthesis of Anglo-Saxon sources', GS (1996), pp. 97-127; ‘A Truly Proud Ruin : Grundtvig and the Anglo-Saxon Legacy' in A. M. Allchin et al. (eds), Grundtvig in International Perspective: Studies in the Creativity of Interaction (Aarhus, Oxford and Oakville CT, 2000), pp. 147-162.

10. Beowulf, translated by Seamus Heaney (Faber and Faber, London 1999). 'Englands of the Mind', The 1976 Beckman Lecture, published in Preoccupations: Selected Prose 19681978 (London, 1980). The following observations are repeated from my paper 'Heaney and Grundtvig : relicensing the oldest poetry of the North' at the International Grundtvig Consultation, York UK 2000, to be published in due course on the website Grundtvig in England (www.grundtviginengland.org.uk).

11. See the introduction to Heaney's Beowulf, p. xxv.

12. Nyeste Skilderie af Kjøbenhavn, no. 72 (Saturday 9 September, 1815), cols. 1139-40.

13. Helge Toldberg, Grundtvig som filolog (Copenhagen, 1946); G. Albeck et al. (eds), Registrant over N. F. S. Grundtvigs Papirer, Vols. I-XXX (Copenhagen 1957-64) - »det angelsaksiskes fremtrædende plads i etymologiseringen « (notes to Fasc. 268, nr. 16).

14. The only available edition was the one published in Oxford in 1698. Grundtvig's main interest was probably in the Anglo-Saxon translations of the Latin metrical sequences of Boethius. Later, in the Introduction to his Bjowulfs Drape, p. XXXI, he says rather severely that these have "... næsten kun Bogstav-Rimet tilfælleds med Digtene i Cædmons Smag, hvad enten de saa ere af Kong Alfred, eller, hvad jeg finder rimeligere, af en Grammatiker i det $10 \mathrm{de}$ Aarhundrede, der, blottet for Poesie, kun forstod at skrive correcte Vers « [nearly the alliteration alone in common with the poems in the manner of Cædmon, whether they are by King Alfred or, as I find more plausible, by a grammarian of the 10th century who, devoid of poetry, understood only how to write correct verse]. 
15. 'Sachser og Angel-Sachser' in Haandbog $i$ Verdens-Historie, Anden Deel (Copenhagen, 1836), pp. 198-246.

16. From about 1815 , according to the estimation of the editors of Registrant XIV, commenting upon Fasc. 329, Grundtvig began making lists of Anglo-Saxon words, sometimes culling them from Edward Lye's Dictionarium saxonico- et gothico-latinum (2 vols, London, 1772), sometimes from printed texts. Sometimes he glossed them in Danish or in Latin; sometimes he brought to bear his already-established interest in Icelandic etymology to pursue cognates in both these ancient northern languages. Fasc. 329, nos. 1-3 contain a list of »Mærkelige Ange[1]sacsiske Ord« [notable Anglo-Saxon words]. On pp. 1r-2v is an extensive alphabetically arranged list of Old English words from a wide range of (uncited) source texts, with Danish or Latin glosses. On pp. 13r-16v an alphabetical Old English/ Danish alphabetical word list is compiled from Lye, letters A-E. On pp. 17r-18v and 19r$24 \mathrm{v}$ occurs another Old English/Danish alphabetical word list, entitled $» D a n s k-$ Angelsaxiske Ord«. In Fasc. 329, nos 4-5, on pp. 25r-25v, Grundtvig shows his interest in the Anglo-Saxon word wyrd (event, fate, destiny, 'Weird', Providence) - of which word he will have read an important Christian definition by Alfred in the course of the king's translation of Boethius. He notes its later occurrence in the poetry of the medieval Scots poet Gavin Douglas and in Chaucer's Troilus and Criseyde. He also annotates the conceptually related Anglo-Saxon word metod (the Measurer, the Ordainer, God) together with its Icelandic cognates, glossing them in Latin. In Fasc. 328, item 20, p. 41r-41v, another list of Old English words occurs, evidently drawn from various texts, glossed in Latin; and in the same Fascicle, item 6, p. 8r, a list of some twenty words and phrases, with page and line references, from 'Cædmon' - that is, from the poems contained in Oxford Bodleian Library MS Junius 11. He made similar lists of Icelandic words and phrases, which survive for example in Fascicle 268. The etymologist, the searcher for the spirit of the North, the translator and poet are all potentially served by these listed observations.

17. Nyeste Skilderie af København, 3rd and 6th February, 1810.

18. Nyeste Skilderie af København, 20th January, 1810, cols. 465-473.

19. Det handlende ord: N. F. S. Grundtvigs digtning, litteraturkritik og poetik 1798-1819 (Copenhagen, 1980), Første del, p. 316 and p. 317. This book, incidentally, itself urgently needs translating into English.

20. Lundgreen-Nielsen, p. 317.

21. In his own journal, Den Nordiske Kirke-Tidende 4 (1833), cols. 63-64.

22. In Danne-Virke Et Tids-Skrift afN. F. S. Grundtvig, II (Copenhagen, 1817), pp. 65-96. The item comprises a short account of the source and background of the poem, a somewhat overstated summary of England's neglect of her Tungemaal and ancient poesy, some discussion of textual cruces, and a translation of the poem in a ballad-like strophic form of four lines (rhyming $a b a b$ ) with an unrhymed $(c d)$ refrain ("Immortal fame at Brunanburh the princes have won themselves«). It is followed by a verse Efterklang - a kind of meditation, prompted by the Anglo-Saxon poem, upon the role of the latter-day verse-translator in relaying onwards Faedrenes Aand, the spirit of the forefathers. Its 
extreme modesty should perhaps not be taken too seriously: »Jeg er ei Skjald, ei heel, ei halv, / Det vil jeg høit erklære, / Jeg pløier med de Gamles Kalv, / Der ligger al min Ære. // Mit Kvad er kun en Efterklang, / Af Fædres Kæmpevise, / Og derfor strækker kun min Sang, / Til Fædrene at prise.« [p. 96: I am no skjald, not whole, not half, that I will declare out loud. I plough with the forebears' calf, there lies all my honour. My verse is just an echo of the fathers' warrior-lays, and therefore my song serves only to esteem the fathers]. The text is actually an annal (dated 937) in the Anglo-Saxon Chronicle.

23. The statement continues: "...men da godt Folk slet ikke kan finde sig i mine Talemaader, maae de for mig kalde følgende Vers hvad de vil... « [...but since worthy folk just cannot go along with my ways of speaking they may, as far as I am concerned, call the following verses what they like...]. Evidently, Müller's mild observation about vilkaarlig Paraphrase still rankles.

24. 'Stykker af Skjoldung-Kvadet eller Bjovulfs Minde', in Danne-Virke IV (1819), pp. 234262.

25. Line references are to C. L. Wrenn's third edition of Beowulf, revised by W. F. Bolton (London, 1973). An invaluable resource for Beowulf studies, which includes material by and on Thorkelin and Grundtvig, is The Electronic Beowulf (2 CD-Roms Mac/Windows), ed. K. Kiernan et al. (British Library and University of Michigan Press, 2000); see, for information, www.uky.edu/ kiernan/eBeowulf/guide.html.

26. Grundtvig, in a lecture at Borchs Kollegium, 23 November 1838; in S. Grundtvig (ed.), Mands Minde 1788-1838. Foredrag over det sidste halve Aarhundredes Historie (Copenhagen, 1877). Thanks to Dr Tine Damsholt for this reference: 'Grundtvig and the idea of democracy', paper given at the International Consultation on N. F. S. Grundtvig, York UK 2000 , forthcoming at www.grundtviginengland.org. $u k$.

27. This passage is discussed below, alongside the corresponding Anglo-Saxon.

28. In his 'Svar til: »Et Par Ord..."' (Skilderie no.68, col. 1076), Thorkelin claims that Grundtvig has misunderstood stapol: »I 14de Sang vil Hr. G. at Hrodgar stod paa Gulvet, som han oversætter fra Stapol. Dette Ord, hvoraf det Engelske Steeple kommer, betyder dog et Taarn, et høit Sted " [In the 14th Song Mr G. wants to have Hrothgar standing on the floor, which he translates out of stapol. This word, from which the English Steeple derives, means a tower, a high place]. In fact, scholars today are still not confidently agreed on a precise meaning for the word. It is shrewd of Grundtvig here in his Bjowulfs Drape to skirt round the problem entirely by omitting any reference to an architectural feature of any kind. Instead, Hrothgar stands 'stille'.

29. Niels Lyhne Jensen et al., A Grundtvig Anthology: Selections from the Writings of N. F. S. Grundtvig, 1783-1872 (Cambridge and Viby, 1984), p. 20.

30. Am I exposing my own limited sense of what rings true and false in Danish today, when I say that I find Bjowulfs Drape a genuinely engaging and enjoyable read, full of those moments of delight in language consummately used in poetry that one expects of a masterwork; and that it seems to me timely that Bjowulfs Drape should be revisited as a Danish classic of 'translation' too long neglected, and made available again to a mature Danish readership (and ideally also to a $\mathrm{CD}$ audience, since this is a text composed for 
listening to, which does seem to me to recite exceedingly well), in a popular edition which would blend the scholarly with the folkelig? This paper was written during a research-stay at Vartov in September 2000. My gratitude goes once more to Kirkeligt Samfund and to the admirable team which runs Vartov and the Grundtvig-Bibliotek, for all hospitality, help and friendship. 